\title{
SCIENTIFIC THOUGHT AND ITS MEANING FOR RELIGION : THE IMPACT OF FRENCH SCIENCE ON BRITISH NATURAL THEOLOGY, 1827-1859
}

\author{
INTRODUCTION
}

Historians of the Siècle des Lumières have frequently proposed a contrast. In France, scientific advances were seized upon by the philosophes in their attacks on the Christian faith. In England, instead of antagonism, there was an integration of science and religion until well into the 19th century ${ }^{1}$. There are well-known stories of Englishmen visiting France and expressing their surprise when they were told that science had made christianity untenable. As radical a figure as Joseph Priestley was struck by what he found :

« When I was dining at [...] Turgot's table, M. de Chastellux [...] said the two gentlemen opposite me were the Bishop of Aix and the Archbishop of Toulouse, "but", said he, " they are no more believers than you or I". I assured him I was a believer; but he would not believe me ${ }^{2}$.

Priestley's discomfort is particularly telling because he was well known as a religious radical, a Unitarian critic of the Anglican Church, a sympathizer with the American Revolution, a student of the sciences whose laboratory was burned by a Birmingham mob because of his identification with the Revolution in France. Priestley, indeed, had been so outspoken in his claim that Protestant, as well as Catholic, theology

1. See, for example, the essays by N. Hampson and R. Porter in Roy PoRTER, Mikuláš TEICH, eds, The Enlightenment in National Context, Cambridge, Cambridge University Press, 1981. For a discussion of the relationship between concepts of the unity of knowledge and the introduction of the physical sciences into the French universities in the 18th century, see L.W.B. BROCKLISS, French Higher Education in the Seventeenth and Eighteenth Centuries: A Cultural History, Oxford, Clarendon Press, 1987.

2. Cited by Derek ORANGE, "Oxygen and One God", History Today, 24, 1974, p. 773781 , p. 781 .

Revue de synthèse: IV S. No 1, janv.-mars 1989. 
had been corrupted that, after his death, he was duly reproached by Cuvier. In his éloge, Cuvier contrasted Priestley's careful work in science with his careless, rash career as a theologian. To be exiled in America was a just reward for a man accused of reversing all religion and morality ${ }^{3}$.

Priestley was one of the most radical thinkers of the Enlightenment, often hated in England for his advocacy of a general religious toleration. Yet he was convinced that science and a purified version of christianity supported each other. Even the science of chemistry showed that nature was a designed system. His own work on the rudiments of what eventually became known as photosynthesis showed the benevolence of a God who, by filling the Earth with vegetation, had ensured that there would always be purified air for men to breathe ${ }^{4}$. Even Priestley illustrates what one historian has called that peculiarly English phenomenon : a holy alliance between science and religion ${ }^{5}$.

Since I have analysed the reasons for this alliance elsewhere ${ }^{6}$, my object in this paper is to examine its fortunes in the 19th century. It eventually broke down as both science and theology became professional academic disciplines, each with its own criteria for acceptable work. It broke down as a younger generation of scientific publicists, of whom T. H. Huxley is perhaps the most famous example, challenged the credentials of the clerical amateur, the clergyman-naturalist, for whom natural theology had fulfilled a unifying function ${ }^{7}$. It broke down as

3. Toby A. APPEL, "The Cuvier-Geoffroy Debate and the Structure of NineteenthCentury French Zoology ", Princeton University Ph. D. Dissertation, 1975, p. 108-109.

4. On Priestley's conception of nature as a designed system, see John G. McEvoY, « Joseph Priestley, Aerial Philosopher : Metaphysics and Methodology in Priestley's Chemical Thought, from 1762 to 1781 », Ambix, 25, 1978, p. 1-55, 93-116, 153-175, especially p. 164 ; John Hedley Brooke, « A Sower Went Forth : Priestley and the Ministry of Reform ", in Oxygen and the Conversion of Future Feedstocks, Proceedings of the Third British Oxygen Company Priestley Conference, London, Royal Society of Chemistry, 1984, p. 432-460; Simon SCHAFFER, "Priestley and the Politics of Spirit", in Robert G. Anderson, Christopher J. LAWrence, eds, Science, Medicine and Dissent: Joseph Priestley, 1733-1804, London, Science Museum and Welloome Institute, 1987; ID., " Priestley's Questions : An Historiographic Survey ", History of Science, 22, 1984, p. 151183.

5. Basil Willey, The Eighteenth-Century Background, New York, 1941, p. 136; N. GARFINKLE, "Science and Religion in England, 1790-1800 », J. Hist. Ideas, 16, 1955, p. 376-388.

6. J.H. Brooke, "Why Did the English Mix Their Science and Their Religion? », in Sergio RossI, ed., Science and Imagination in Eighteenth-Century British Culture, Milan, Edizioni Unicopli, 1987, p. 57-78; ID., " The Natural Theology of the Geologists : Some Theological Strata ", in Ludmilla J. JoRDANOVA, R. PORTER, eds, Images of the Earth, Chalfont. St. Giles, British Society for the History of Science, 1979, p. 39-64.

7. Frank M. TURNER, "The Victorian Conflict between Science and Religion : A Professional Dimension ", Isis, 69, 1978, p. 356-376; James R. MooRE, "Geologists and Interpreters of Genesis in the Nineteenth Century $»$, in David C. LINDBERG, Ronald L. NUMBERS, eds, God and Nature: Historical Essays on the Encounter between Christianity 
movements for political reform disrupted the analogies which, during the 18th and early 19th centuries, had been sustained between a stable social order and a stable natural order. Its intellectual justification in the argument from design was to receive a formidable blow from Charles Darwin's Origin of Species (1859). The attempt to discern design in nature was not actually destroyed, either before Darwin or after. But the plausibility of the arguments by which a theistic reading of nature was sustained had already suffered in the period leading up to Darwin's publication.

I hope to illustrate this point by referring to the work of four British scientists, William Buckland, Charles Lyell, William Whewell and Richard Owen. In each case a comparison will be drawn with a French scientist who had similar interests. Buckland will be compared with Cuvier, Lyell with Lamarck, Whewell with Laplace, and Owen with Geoffroy Saint-Hilaire. These comparisons have been chosen because, in each case, the British scientist helped to popularize the French science. But since, in each case, the French science posed a threat to religious belief, the process of popularization involved a transformation of the science. Ideas coming from Paris were neutralized and given alternative meanings as they were absorbed within a framework of natural theology.

The argument of this essay is that, although natural theology was able to absorb the scientific innovations, it was itself transformed through the process of assimilation. As it diversified, it became increasingly fragile. If one of its functions had been to disarm those who saw in science a threat to religion and social stability, it lost much of its efficacy as arguments for a divine Legislator were coupled with naturalistic accounts of human evolution which, hitherto, had been largely the property of popular radicalism $^{8}$.

\author{
BUCKLAND AND CUVIER
}

William Buckland has attracted attention for his valiant attempt to create space for the study of geology in the University of Oxford. His recent biographer claims him as the founder of an English school of

and Science, Berkeley/Los Angeles/London, University of California Press, 1986, p. 322350.

8. Adrian DESMOND, "Artisan Resistance and Evolution in Britain, 1819-1848 ", Osiris, $2^{\text {nd }}$ series, 3,1987 , p. $77-110$. 
geology, distinguished by its research on the Secondary rocks ${ }^{9}$. Buckland himself enjoys a somewhat notorious reputation for his argument that certain geological features could not be explained unless there had been a recent, universal flood ${ }^{10}$. By way of a reprieve, it has been suggested that his interest in the action of torrents of water predisposed him towards accepting the glacial theory of Louis Agassiz ${ }^{11}$.

Buckland's interests overlapped with those of Cuvier. He undertook first-hand work on fossil bones in English caves. The Kirkdale cave in Yorkshire, he decided, must have been a hyena den. As with Cuvier, his knowledge of paleontology convinced him that certain species had become extinct during the Earth's long history. As with Cuvier, he adopted the hypothesis of catastrophic events to explain the extinction. Building on Cuvier's conception of the fossil record, he argued that organic forms had shown greater complexity over the course of time. The fitness of the world for animal life, he surmised, « appears to have been progressive " ${ }^{12}$. When Cuvier died, it was Buckland who gave the éloge. Addressing the British Association for the Advancement of Science, at its Oxford meeting in 1832, he compared Cuvier with Pliny and Aristotle. He particularly praised Cuvier's method of treating each organism as an integrated whole, stressing to an English audience the manner in which his French colleague had spoken of the correlation of parts and the coordination of functions ${ }^{13}$. Cuvier had made the impressive, albeit extravagant, claim that he could reconstruct fossil quadrupeds from minimal fragments ${ }^{14}$.

As Buckland continued his éloge, he claimed to be a friend of Cuvier. He particularly commended the hospitality which visitors to Paris had enjoyed in that "well known mansion in the Jardin des Plantes " ${ }^{15}$. The connections between the two men were even stronger because Buckland had boosted his own prestige by corresponding with Cuvier, whose

9. Nicolas A. RuPKE, The Great Chain of History: William Buckland and the English School of Geology, 1814-1849, Oxford, Clarendon Press, 1983.

10. William BuCKLAND, Reliquiae Diluvianae, London, Murray, 1823; ID., Vindiciae Geologicae, Oxford, Oxford University Press, 1820; Charles Coulston GiLlisPIE, Genesis and Geology. The Impact of Scientific Discoveries upon Religious Beliefs in the Decades before Darwin, New York, Harper \& Brothers, 1959, chap. Il-V.

11. Cf. N. A. RuPKE, op. cit. supra n. 9, p. 105-107.

12. Ibid., p. 159.

13. W. BUCKLAND, Report of the... British Association for the Advancement of Science, 1832, London, 1833, p. 104-105.

14. William Coleman, Georges Cuvier : Zoologist, Cambridge, Mass., Harvard University Press, 1964.

15. Cf. W. BuCKLAND, op. cit. supra n. 13. 
assistant, Joseph Pentland, acted as intermediary ${ }^{16}$. It was a two-way correspondence because Cuvier, in turn, asked Buckland to provide him with some hyena bones when he was working on the fossil carnivores. Buckland had the satisfaction of seeing his own interpretation of the hyena den confirmed by Cuvier ${ }^{17}$.

Given their common interests, one would expect a certain similarity of style in their work. Buckland did indeed claim that he entirely coincided with the views of Cuvier on the evidence for a recent flood. In this he was deceived. Cuvier had suggested that, during the biblical flood, land and sea had changed places. Buckland had seen no need for this and so was quite prepared for the discovery of fossil man in diluvial remains ${ }^{18}$. But there were other differences, too, particularly in the religious meaning which each attributed to his science. The extent to which Cuvier's science was structured by his Protestant christianity is still a matter for debate ${ }^{19}$. His recent biographer, Dorinda Outram, has emphasized his rationalism and an aversion to the intrusion of biblical motifs ${ }^{20}$. But with the popularization of Cuvier's science in England, its tone was changed. As it was absorbed within natural theology, its content changed too.

Whereas Cuvier had spoken of local catastrophes, it became common to represent them as universal. The poet Byron claimed that he had adopted Cuvier's position in supposing that the world had been destroyed several times before the creation of $\operatorname{man}^{21}$. Cuvier's catastrophes could also be presented as supernaturally controlled, with new species created after each cataclysm. Buckland himself speculated that many new species had been created since the biblical flood ${ }^{22}$. Cuvier, by contrast, had been reticent on the subject of creation, preferring to correlate the appearance of new species with migration :

"When I maintain that the stony layers contain the bones of several genera and the earthy layers those of several species which no longer exist, I do not mean that a new creation has been necessary to produce the existing species,

16. William Antony S. SARjEANT, Justin B. Delair, "An Irish Naturalist in Cuvier's Laboratory: The Letters of Joseph Pentland, 1820-1832 ", Bull. Brit. Mus. (Nat. Hist.), Hist. Ser, 6, 1980, p. 245-319.

17. Cf. N. A. RUPKE, op. cit. supra n. 9, p. 12, 31, 36.

18. Ibid., p. $38-41$.

19. Cf. T. A. APPEL, art. cit. supra n. 3, p. 107-112.

20. Dorinda OutRaM, Georges Cuvier, Manchester, Manchester University Press, 1984, p. 143-151.

21. Cf. N. A. RuPKE, op. cit. supra n. 9, p. 75.

22. Ibid., p. 92. For further discussion of the gloss placed on Cuvier's science in England, see Martin J. S. RuDwCK, The Meaning of Fossils : Episodes in the History of Paleontology, London/New York, Macdonald/American Elsevier, 1972, p. 115-117, 132-133. 
I merely say that they did not exist in the same localities and must have come $[\ldots]$ from elsewhere $" 23$.

The change in tone as Cuvier was transported to England can be heard by comparing the discordant reverberations of Earth history as presented by Cuvier in his Preliminary Discourse with the harmonies projected by Buckland. Cuvier spoke of former life repeatedly disturbed by calamitous events, of countless beings which had succumbed in these upheavals. Some had been destroyed by floods, others perishing as the sea-bed rose. Entire species had vanished for ever ${ }^{24}$. A few years earlier, the doyen of natural theology in England, William Paley, had blithely asserted that it was a happy world, after all! The question for British natural theologians was whether the sting could be removed from the awareness of extinction. Buckland's strategy was to treat each stage of Earth history as a preparation for the next. Each new epoch created opportunities for more complex creatures which were well-adapted to their environment as it then was. Provision had been made during the Earth's development for the eventual arrival of man - particularly the Englishman. For Buckland's God was an Anglophile who had arranged that iron ore, limestone and coal would be found in the same localities, providing all the ingredients of an industrial revolution ${ }^{25}$.

In his public lectures, Buckland tried to graft a moral lesson onto Cuvier's science. Addressing the British Association in 1832, he claimed that his French colleague had demonstrated the " unity and universal goodness of the great Creator " . In fact, as Outram has suggested, there is a sense in which, by staking out his claim to be the discoverer of the past, Cuvier had turned himself into the great creator, surpassing those who were content to decode a Providential plan ${ }^{26}$. Onto Cuvier's principle of the correlation of parts, Buckland grafted the conclusion that even extinct forms had been well-designed in their day, " fashioned by the same Almighty hand $»{ }^{27}$. Cuvier had not so explicitly argued for design.

The meaning of Cuvier's science for religion was changed through the process of popularization. The threat from Paris was not merely neutra-

23. Cited from Cuvier's Recherches sur les ossemens fossiles, Paris, 1812, vol. 1, p. 81, by E. S. Russell, Form and Function, London, Murray, 1916, p. 43.

24. Cf. D. Outram, op. cit. supra n. 20 , p. 156.

25. Cf. C.C. GillisPie, op. cit. supra n. 10 , p. 104 ; cf. N. A. RUPKE, op. cit. supra n. 9, p. 261-266. For a sensitive, rather than censorious, treatment of Buckland, and of teleological reasoning in early geological systems, see Stephen Jay GoulD, Hen's Teeth and Horse's Toes, New York/London, Norton \& Company, 1983, p. 79-93.

26. Cf. D. OUTRAM, op. cit. supra n. 20 , p. 152.

27. Cf. W. BUCKLAND, op. cit. supra n. 13, p. 105. 
lized, but turned to advantage. Providence was protected through schemes of progressive creation. But in meeting the threat, natural theology was itself transformed. One could rationalize the fact of extinction as part of the divine plan, but emotionally it could still be profoundly disturbing, as Tennyson explored in his poem In Memoriam ${ }^{28}$. The indifference of nature towards the individual life was compounded by an indifference towards the type, towards entire species. The fact that so many pre-historic species could be described as monsters was a further problem. The threat from the giant sloth was a principal theme of Buckland's 1832 address. The challenge had been issued by Buffon, who had implied that the beast was not one of nature's success stories : its grotesque fore-limbs were out of all proportion, all harmony. It had been doomed by its own dissonance.

Not so, Buckland replied. Against so impious an insinuation, he argued that the sloth had been perfectly designed to excavate roots deep beneath the ground. Taming the beast, he christened it "Old Scratch " and proceeded to show how, once its life-style had been deduced, it was no longer anomalous. Had it been let loose in Lincolnshire, it would have dug a famous gutter! Only one problem remained. The posterior of the sloth exceeded the bulk of the largest elephant and its claws were more than a foot long. And yet Buckland had the answer. Its proportions had been designed to enable the creature to stand at ease on three legs, so that one of its fore-paws could be exercised, without fatigue, as it foraged for food $^{29}$.

Buckland's lecture has been called the high point of natural theology in England, as science was made subservient to the religious and classical values of her oldest university. It was undoubtedly a remarkable occasion. As one witness recorded :

«In the evening went to the Music Room and heard the lecture of Dr. B. on the Megatherium ! A very admirable discourse : the room crowded to excess : terminated at $12 o^{\prime}$ clock at night ${ }^{30}$.

Buckland's message was that God cared for his creatures after all. But, in developing the argument, he publicized the uncomfortable truth that the Earth had seen many revolutions before the biblical flood.

28. Susan GlisERMAN, « Early Victorian Science Writers and Tennyson's In Memoriam ", Victorian Studies, 18, 1975, p. 277-308, 437-459.

29. Cf. W. BuCKLAND, op. cit. supra n. 13, p. 106.

30. Cited from the Journal of Gideon Mantell by N. A. RUPKE, op. cit. supra n. 9, p. 244 . 
One British observer who perceived the differences between Buckland and Cuvier was another geologist, Charles Lyell. Buckland had been Lyell's teacher, but the pupil has traditionally been given the greater prominence. Lyell is often credited with having placed geology on a modern footing by excluding theological considerations from the study of Earth history ${ }^{31}$. He is noted for his insistence that the forces which shaped the Earth's surface in the past were the same as those acting now - both in kind and intensity ${ }^{32}$. He has been praised for his extension of the age of the Earth, which enabled him to explain away catastrophes as illusions. Given enough time, gradual processes could achieve mighty effects. Lyell was also an innovator in the repertoire of reasons he gave to explain why the fossil record was necessarily imperfect. He rejected the anthropomorphism which assumed that nature had intended to leave a complete catalogue of her products. This was to be a vital resource for Charles Darwin as he struggled with the gaps in the fossil record which seemed to compromise his gradualism ${ }^{33}$.

In several respects Lyell resembled Lamarck. Each drew on indefinite draughts of time; each turned his face against catastrophist histories; each eliminated divine intervention in the Earth's physical development. Lamarck had done the same for its organic development, treating what had once been God's creatures as products of transformation ${ }^{34}$. One of

31. Cf. C. C. GillisPie, op. cit. supra n. 10, chap. v; Leonard G. Wilson, Charles Lyell. The Years to 1841 : The Revolution in Geology, New Haven, Yale University Press, 1972. For alternative perspectives in which it is not assumed that an antithesis between uniformitarianism and catastrophism was either complete, or congruent with a naturalism/supernaturalism dichotomy, see R. HoOYKAAS, Catastrophism in Geology : Its Scientific Character in Relation to Actualism and Uniformitarianism, Amsterdam/London, North Holland Publ. Co, 1970; M. J. S. RuDWICK, "Uniformity and Progression : Reflections on the Structure of Geological Theory in the Age of Lyell ", in Duane H.D. Roller, ed., Perspectives in the History of Science and Technology, Norman, University of Oklahoma Press, 1971, p. 209-227.

32. M. J. S. RuDwick, “ The Strategy of Lyell's Principles of Geology ", Isis, 61, 1970, p. 5-33.

33. Charles DARWIN, On the Origin of Species by Means of Natural Selection, London, 1859, chap. IX.

34. L. J. Jordanova, Lamarck, Oxford, Oxford University Press, 1984; Richard W. BuRCKHARDT Jr., The Spirit of System : Lamarck and Evolutionary Biology, Cambridge, Mass., Harvard University Press, 1977; Pietro Corsi, The Age of Lamarck, Berkeley, University of California Press, 1988. On Lamarck's introduction into England and influence on Lyell, see Goulven LAuRent, Paléontologie et évolution en France, 1800-1850, Paris, Éd. du C.T.H.S., 1987, p. 235-239. For a review of recent French literature on Lamarck, 
the basic ideas behind Lamarck's transformism was that gradual changes in the environment induced gradual changes in living organisms. New needs gave rise to new habits which in turn led to modifications of structure. In explaining the resemblances between fossil and extant marine species, Lamarck had favoured such transformation rather than extinction. Hence one of the bones of contention between himself and Cuvier $^{35}$.

Lyell was already familiar with trends in French science before he wrote his celebrated Principles of Geology (1830-1833). In September 1830 he had spent six weeks working in the private museum of Gerard Paul Deshayes who had been closely associated with Lamarck and an admirer of his system of classification ${ }^{36}$. From Paris, Lyell wrote a letter to his sister which shows that Lamarck's theory had been on his mind. He told her of the enormous life-span of a particular shell, adding, with irony, that it must have required a good time for the Orang-Outang to become man on Lamarckian principles ${ }^{37}$. Lyell probably did more than anyone in England to acquaint scholars with Lamarck's theory, though the young Charles Darwin was initiated by his Edinburgh mentor, Robert Grant ${ }^{38}$. But if Grant aimed to popularize Lamarck as an advocate, Lyell succeeded in so doing as an adversary. French transformism was too great a threat even for one such as Lyell with anti-clerical leanings ${ }^{39}$. There has been considerable support for Michael Bartholomew's thesis that Lyell's repudiation of Lamarck is the key to understanding his own distinctive view of the fossil record ${ }^{40}$.

In 1826 Lyell had been content to adopt a scheme of progressive creation, not dissimilar to that of Buckland. It was possible to infer that

see Jean-Marc DrouIN, «Lamarck ou le naturaliste philosophe », Corpus, Revue de Philosophie, 3, 1986, p. 29-35.

35. R.W. BURCKHARDT Jr., « The Inspiration of Lamarck's Belief in Evolution », J. Hist. Biol., 5, , 1972, p. 413-438.

36. P. CoRsi, «The Importance of French Transformist Ideas for the Second Volume of Lyell's Principles of Geology ", Brit. J. Hist. Sci, 11, 1978, p. 221-244, p. 222, 227, 228.

37. Cited in ibid., p. 228.

38. Phillip R. SLoAN, «Darwin's Invertebrate Program, 1826-1836 : Preconditions for Transformism ", in David KoHN, ed., The Darwinian Heritage, Princeton, Princeton University Press, 1985, p. 71-120.

39. For the reaction to Grant's Lamarckism, see A. DeSMOND, « Robert E. Grant : The Social Predicament of a Pre-Darwinian Transmutationist ", J. Hist. Biol., 17, 1984, p. 189223, 216-220.

40. Michael Bartholomew, « Lyell and Evolution: An Account of Lyell's Response to the Prospect of an Evolutionary Ancestry for Man ", Brit. J. Hist. Sci., 6, 1973, p. 261-303; ID., " The Singularity of Lyell ", History of Science, 7, 1979, p. 276-293. 
« in ascending from the lowest to the more recent strata, a gradual and progressive scale could be traced from the simplest forms of organization to those more complicated, ending at length in the class of animals most related to $\operatorname{man}{ }^{4}{ }^{4}$.

Soon, however, he was to abandon this sense of direction in the fossil record. Why? The answer appears to be that, in February 1827, Lyell read Lamarck. Thereafter he resisted the concept of a linear progression. In his Principles of Geology he would argue that the main genera were represented throughout the fossil record. The absence of mammals in earlier formations was simply an illusion due to the imperfection of the record. Reading Lamarck had produced a volte-face.

Evidence from several sources suggests that Lamarck's theory deeply disturbed him. In a well-known letter to Darwin, he later recalled how he had reacted : " I remember that it was the conclusion he came to about man that fortified me thirty years ago against the great impression which his arguments at first made on my mind $" 42$. However persuasive Lamarck's reasoning had been, an animal ancestry for man was unpalatable. Whilst in Paris, Lyell would realize that Lamarck's ideas on evolution were a force to be reckoned with. Concepts of organic transformation were being developed by Deshayes, Bory Saint-Vincent and Geoffroy Saint-Hilaire. As Pietro Corsi has observed, Lyell's worst fears would have been made concrete during that six-weeks stay in the autumn of $1830^{43}$. He went back to England determined to put a stop to theories which threatened to drag humanity down to the level of the beasts.

The most conclusive evidence that Lyell was haunted by Lamarck comes from the second volume of the Principles of Geology where every possible objection was raised against the transmutation of species ${ }^{44}$. The most poignant was that to accept Lamarck was to strip men and women of their unique status as rational beings. Lyell's strategy was to show that there was no linear pattern of development, visible in the fossil record, that could possibly support Lamarck's notion of an inherent tendency to complexity in all living systems.

Lyell claimed that his attack on Lamarck was not inspired by any odium theologicum, and this may be true. But, in Lyell's vision of Earth history, in contrast to that of Lamarck, there was a residue of natural theology. The French naturalist had tried to deny the fact of extinction

41. Ibid., 1973, p. 269.

42. Lyell to Darwin, 15 March 1863, cited in ibid., p. 275.

43. Cf. P. Corsi, art. cit. supra n. 36, p. 230.

44. Ibid., p. 232-242; William Coleman, "Lyell and the "Reality" of Species : 18301833 ", Isis, 53, 1962, p. 325-338. 
but, for Lyell, extinction was the price extracted by nature for the fact that each new species was well-adapted to its environment. If the environment changed, it was simply too imaginative on Lamarck's part to expect that organisms could undergo physical change in order to readjust. Lyell would claim that there was evidence for a "Presiding Mind " in the fact that new species were introduced only when there was an environment ready to receive them ${ }^{45}$. This preadaptation, with its religious overtones, was the presupposition he brought to the problem of the geographical distribution of animals, and it was one with which Darwin had to break $^{46}$. Very selectively, Lyell drew on the work of Alphonse de Candolle who had argued for the similarity of genera, though not of species, in similar geographical areas ${ }^{47}$.

Lyell's thinking was still constrained by assumptions drawn from natural theology. His Principles of Geology has been described as a Bridgewater Treatise sanitized of an explicit religious vocabulary ${ }^{48}$. In his belief that every habitable environment would have its occupants, there was a survival of the ancient concept of plenitude. Through his dialogue with Lamarck's all-embracing naturalism, some scope for a natural theology was preserved, rather than destroyed. At the same time, a further transformation had occurred in that Lyell saw no reason to exclude a natural mechanism for the introduction of non-human species, even if he was clueless as to what it might be ${ }^{49}$. When Darwin later convinced him that the transmutation of species was a viable concept, Lyell remembered his earlier dialogue with Lamarck. He could then safely say that he regretted having been so critical and even annoyed Darwin by implying that his theory of natural selection was only a variant of Lamarck's.

45. Edward BAILEY, Charles Lyell, London, Thomas Nelson, 1962, p. 93 ; D. KoHN, "Theories to Work By: Rejected Theories, Reproduction, and Darwin's Path to Natural Selection », Stud. Hist. Biol., 4, 1980, p. 67-170, p. 68-72.

46. Michael Jonathan S. HODGE, "Darwin and the Laws of the Animate Part of the Terrestrial System (1835-1837): On the Lyellian Origins of his Zoonomical Explanatory Program ", Stud. Hist. Biol., 7, 1982, p. 1-106.

47. Dov OSPoVAT, "Perfect Adaptation and Teleological Explanation : Approaches to the Problem of the History of Life in the Mid-Nineteenth Century ", Stud. Hist. Biol., 2,1978 , p. 33-56, 40-41.

48. Cf. D. KOHN, art. cit. supra n. 45 , p. $68-72$.

49. Cf. M. BARTHOLOMEW, art. cit. supra n. 40 , 1973, p. 287-289. 
The possibility that Lamarck might be popularized, even in the act of refuting him, was recognized by one of Lyell's most astute critics, the Cambridge philosopher and polymath, William Whewell. Born in Lancaster, the son of a master-carpenter, he eventually rose to become Master of Trinity College. When, in the 1850s, he challenged the dogma of a plurality of worlds, many were the jibes that he had thereby secured his place in the most prestigious lodge in the universe ${ }^{50}$. Whewell is increasingly recognized as a seminal figure in 19th-century British science. It was he who coined the word " scientist " and who campaigned to introduce the natural sciences as an examinable subject at Cambridge. His work as a philosopher of science is still attracting attention - not least for his conviction that different sciences had distinctive methodological requirements of their own ${ }^{51}$. He promoted French analytical methods in the teaching of mathematics at Cambridge ${ }^{52}$ and spearheaded the Oxbridge take-over of the newly formed British Association for the Advancement of Science ${ }^{53}$.

In the early part of his career, his principal interests were in the physical sciences : mineralogy, mathematics and cosmology. From an early age, he had confessed to a longing for omniscience, which eventually found expression in works on theology, morality and that most demanding of subjects : the history of science. During the early 1830 s he wrote one of the standard texts on natural theology, known as the Bridgewater Treatises, so named because they were funded through the will and estate of the eighth Earl of Bridgewater, who had spent many years of his life exiled in France.

The Bridgewater Treatise shows Whewell adopting an ambivalent attitude towards Laplace. He described him as « one of the great mathemati-

50. J. H. BRoOKE, « Natural Theology and the Plurality of Worlds : Observations on the Brewster/Whewell Debate ", Annals of Science, 34, 1977, p. 221-286.

51. R. R. YEO, « Scientific Method and the Rhetoric of Science in Britain, 1830-1917 ", in John A. SCHUSTER, Richard R. YEO, eds, The Politics and Rhetoric of Scientific Method, Dordrecht/Boston, Reidel, 1986, p. 259-297.

52. H. W. BECHER, «William Whewell and Cambridge Mathematics ", Hist. Stud. Phys. Sci., 11,1980, p. 1-48.

53. Jack MORRELL, Arnold THACKRAY, Gentlemen of Science : Early Years of the British Association for the Advancement of Science, Oxford, Clarendon Press, 1981, p. 425-430. 
cians of modern times "; but, as a metaphysician, he had been misguided in trying to banish final causes from the interpretation of nature. Two aspects of Laplace's work were particularly relevant to Whewell's cosmological interests. Firstly there was his demonstration that the solar system was more stable than Newton had supposed. The famous problem to which Laplace had addressed himself was the long-term consequences of the fact that Jupiter appeared to be slowly accelerating, Saturn slowly decelerating. Would the system require some kind of « reformation" as Newton had proposed; or would it be self-correcting? By 1786, Laplace had shown that the acceleration of Jupiter was balanced by the deceleration of Saturn. In about nine hundred years hence, the two processes would be reversed. Through internal compensation, the solar system could stabilize itself ${ }^{54}$.

Secondly, in his Système du Monde, Laplace had explained the origins of the solar system without any reference to divine activity. Postulating a rotating solar envelope, which contracted as it cooled, he ascribed the origin of the planets to the ejection of rings of matter at successive stages in the contraction. The model was devised to explain why the planets orbited the sun in the same direction and roughly the same plane - a circumstance which Laplace refused to ascribe to chance, or, as Newton had, to the aesthetic sensibilities of God. In the secular atmosphere of the Revolution, Laplace deliberately substituted a physical mechanism for a first cause. In the introduction to his mathematical lectures at the Ecole Normale in 1795 , he had ridiculed the attempts of Leibniz to prove the existence of $\mathrm{God}^{55}$.

The work of Laplace therefore constituted a significant challenge to British natural theology. But the difficulties were not such as to prevent the popularization of his hypotheses in Britain and America. It was quite common for his anti-teleological strictures to be ignored, or for his science to be absorbed within the structures of a religious apologetic ${ }^{56}$. In the judgement of the Scottish physicist, David Brewster, there was no problem at all :

54. Roger HAHN, "Laplace and the Mechanistic Universe", in D.C. LINDBERG, R. L. NUMBERS, eds, op. cit. supra n. 7, p. 256-276, 259-260.

55. Ibid., p. 272. See also Jacques MERLEAU.PoNTY, « Situation et rôle de l'hypothèse cosmogonique dans la pensée cosmologique de Laplace ", Revue d'histoire des sciences, 29 , 1976, p. 21-49.

56. R. L. NUMBers, Creation by Natural Law : Laplace's Nebular Hypothesis in American Thought, Seattle, London, University of Washington Press, 1977; J. H. BROOKE, "Nebular Contraction and the Expansion of Naturalism ", Brit. J. Hist. Sci., 12, 1979, p. 200-211. 
"The loftiest doctrines of natural theology appeal to us with more irresistible force when science carries us back to the Great First Cause, and points out to us, in the atmosphere of the sun, all the elements of planetary worlds so mysteriously commingled $"$ "

Brewster changed the meaning of Laplace's science by pretending that it even confirmed the authority of Scripture :

" In considering our own globe as having its origin in a gaseous zone, thrown off by the rapidity of the solar rotation, and as consolidated by cooling from the chaos of its elements, we confirm rather than oppose the Mosaic cosmogony ${ }^{58}$.

Earlier in the 19th century, other British commentators had met the challenge posed by the new stability of the solar system. The Edinburgh lecturer, John Robinson, renowned among historians for his gallophobia, protested that the analysis of Laplace and Lagrange showed that there was more order, perfection and harmony in the universe than Newton had appreciated. To remove the threat of prospective disorder was to enhance the argument for divine foresight - not, as Laplace had implied, to evacuate it ${ }^{59}$. When Whewell took up the challenge in his Bridgewater Treatise, the process of assimilation had long been under way. But there were at least two reasons why Whewell took a keen interest in the matter. In the first place, Laplace had dared to attack Newton for mixing up his science with his religion ${ }^{60}$. At Trinity College, which had been Newton's home, such a reproach could not be ignored. Secondly, Whewell was in a particularly poignant situation, since, as a clergyman, he was trying to educate his Cambridge congregations, whether in the College Chapel or the University Church. He was strongly motivated to remove their suspicion of science by demonstrating that scientific knowledge led to a greater admiration of the deity. The sermons that he preached in 1827 convey the message that proofs of divine activity based on scientific ignorance were

57. David BREWSTER, « Review of Comte's Cours de philosophie positive ", Edinburgh Review, 67, 1838, p. 271-308, cited by Edward MANIER, The Young Danwin and His Cultural Circle, Dordrecht/Boston, Reidel, 1978, p. 41.

58. Ibid.

59. J. MorReLL, « Professors Robinson and Playfair and the Theophobia Gallica : Natural Philosophy, Religion and Politics in Edinburgh, 1789-1815 ", Notes and Records of the Royal Soc. of London, 25, 1970, p. 43-63; Maurice Crosland, Crosbie SMITH, "The Transmission of Physics from France to Britain ", Hist. Stud. Phys. Sci., 9, 1978, p. 1-61, 11.

60. Cf. R. HAHN, art. cit. supra n. 54, p. 272. 
more shallow than proofs based on the establishment of scientific laws ${ }^{61}$. But the same sermons show that he had hit a snag. In the case of Laplace, the establishment of scientific laws had been given a more sinister interpretation. In Cambridge, nature pointed to nature's God; in Paris, it apparently did not.

Whewell found himself in the position of having to argue that the rejection of final causes by French scientists was an aberration - a mistake due to bad habits of reasoning. His excursions into the history of science, which culminated in his History of the Inductive Sciences (1837), were partly motivated by his wish to prove that the greatest discoveries in science had been made by the pious. Ever the educator, Whewell insisted that, to those with the correct frame of mind, the discovery of natural laws pointed to the Creator who had made them. Laws of nature, properly understood, presupposed an Agent. In Whewell's mind, Laplace was culpable because he had unlearned that great lesson taught by Newton.

How did Whewell meet the challenge? In the first place, he developed the point made by earlier commentators. Surely a solar system that did not need a reformation was even better evidence of design than one which did? If a savage were shown a steam-engine, he would recognize the marks of intelligent design. If he were then shown the self-regulating part of the mechanism, would he not be more, rather than less impressed $^{62}$ ? This absorption of natural law within a wider teleology was a common pattern in 19 th century British and American thought ${ }^{63}$. It was easily achieved because Laplace had set up so clear an antithesis between chance and mechanism when considering the motions within the solar system. British natural philosophers could use the same antithesis but reinterpret it as an antithesis between chance and design. Since Laplace had excluded chance, the solar system must have evolved by design!

Later in his career, Whewell developed his own version of the nebular hypothesis because it helped him in his attack on extraterrestrial life. The more evidence he could muster for true nebulosity in the heavens, the fewer the footholds for beings analogous to man. And if planets had formed by the condensation of swirling gaseous material, there was no reason why any of them need be inhabited. By the early 1850 s Whewell had come to believe that a plurality of worlds was an embarrassment to the Christian religion. The existence of these inhabited worlds had been assumed by Robert Chambers in his popular, but to Whewell subversive,

61. J.H. BroOKE, «Indications of a Creator: Whewell as Apologist and Priest », in Menachem FISCH, Simon SCHAFFER, eds, William Whewell : Studies on his Life and Work, Oxford, Oxford University press, 1988.

62. William WHEWELL, Astronomy and General Physics Considered with Reference to Natural Theology, London, 1939, p. 350.

63. Cf. R. L. Numbers, op. cit. supra n. 56, p. 77-87. 
book Vestiges of the Natural History of Creation (1844). Whewell may also have perceived that the Christian doctrine of the Incarnation could easily be compromised by speculation concerning the spiritual needs of extra-terrestrial beings. A version of the nebular hypothesis, much lamented by his old adversary Brewster, actually helped him in the defence of his religion ${ }^{64}$.

Nevertheless, in Whewell's writings, natural theology was transformed. As he met the challenge from Laplace, he turned the Designer of the universe into a more remote figure. In one sense, the problem was not a new one. It had been felt by all apologists who stressed God's foresight at the expense of His immediate control. But taken to extremes, it could result in the position later adopted by $\mathbf{T}$. $H$. Huxley - that if all the design had been incorporated into the initial state of the universe, then as far as the practice of science was concerned, it would make no difference whether one believed in it or not ${ }^{65}$. Whewell's use of the nebular hypothesis to exterminate extra-terrestrial life was also disturbing to many observers because his stress fell on many features of the universe apparently devoid of purpose. Other worlds were presented by Whewell as analogous to male nipples. They might exhibit patterns of symmetry, but they were barren and useless in themselves ${ }^{66}$.

Because explanations in terms of natural law were susceptible of both a theistic and a positivist interpretation, Whewell had to look elsewhere for a more cogent defence of natural theology and of man's unique status in creation. Increasingly, he had come to rely on an epistemological argument. Why was science successful ? Why were the ideas that regulated scientific research so fruitful? His explanation was that the human mind had been designed in such a way that the discovery of scientific truth was possible. The "fundamental ideas " which regulated research in each branch of science mediated between the human mind and the mind of God ${ }^{67}$. This strong idealist element in Whewell's philosophy of science makes an appropriate introduction to our fourth set of contrasts.

64. Cf. J. H. Brooke, art. cit. supra n. 50, p. 268-273; Michael J. Crowe, The Extraterrestrial Life Debate, 1750-1900: The Idea of a Plurality of Worlds from Kant to Lowell, Cambridge, Cambridge University Press, 1986.

65. Thomas Henry HuXLEY, "On the Reception of the Origin of Species", in Francis DaRwIN, ed., The Life and Letters of Charles Darwin, London, Murray, 1887, vol. 2, p. 179. 204, 201-204.

66. Cf. J. H. BROOKE, art. cit. supra n. 50, p. 282-284.

67. R. R. Yeo, «William Whewell, Natural Theology and the Philosophy of Science in Mid-Nineteenth Century Britain ", Annals of Science, 36, 1979, p. 493-516. 
In common with Whewell, Owen was born in Lancaster and also developed an idealist philosophy of nature. He was widely recognized, especially by himself, as a second Cuvier. Until challenged by T. H. Huxley, he was England's foremost student of comparative anatomy. Unlike Buckland and Whewell, he taught neither at Oxford nor Cambridge. Unlike Lyell, he was not wealthy. His first major post was a Chair at the College of Surgeons in 1836. Some money for his research came from the British Association for the Advancement of Science, in the construction of whose public image natural theology was a prominent motif ${ }^{68}$. He was also assisted by Whewell in making propitious government contacts ${ }^{69}$. The question therefore arises whether the contrast between theistic philosophies of nature in England, and secular, positivist prescriptions in France might not owe something to contrasting channels of patronage. Centralized government support, embodied by an Académie anxious to protect an élitist model of scientific expertise, would militate against constructions of nature which gave explicit support to the Bible, and especially when the tones of a Catholic revival could be equated with a threat from provincial amateurism ${ }^{70}$. It is also possible, as Dorinda Outram has suggested, that the French system, in which it was vital to secure the patronage of powerful individuals, would encourage positivist philosophies of science, in which repeatable experimental results, rather than normative metaphysics, would be emphasized ${ }^{71}$. Insofar as natural theology supplied a normative metaphysics in England, it was certainly sustained by Owen as a badge of social and scientific respectability ${ }^{72}$.

68. Cf. J. Morrell, A. ThaCKRAY, op. cit. supra n. 53, p. 224-245; cf. J. H. Brooke, op. cit. supra n. 6, 1979.

69. A. DESMOND, "Richard Owen's Reaction to Transmutation in the 1830s ", Brit. J. Hist. Sci., 18,1985 , p. $25-50,50$.

70. Cf. T. A. ApPeI, op. cit. supra n. 3, p. 60 et 109; R Fox, "The Savant confronts his Peers : Scientific Societies in France, 1815-1914 ", in Robert Fox, George WeISZ, eds, The Organization of Science and Technology in France 1808-1914, Cambridge, Cambridge University Press, 1980, p. 241-282.

71. D. OUTRAM, "Politics and Vocation : French Science, 1793-1830", Brit. J. Hist. Sci., 13, 1980, p. 27-43; ID., op. cit. supra n. 20, p. 200-202.

72. J.H. BROOKE, «Richard Owen, William Whewell, and the Vestiges ", Brit. J. Hist. Sci., 10,1977, p. 132-145. For the claim that natural theology did provide a common 
Owen has been a problem for historians of science because he had some sympathy for the view that one species could emerge from another as a result of deviation in the development of an embryo. At the same time, in his public remarks, he was hostile to theories which proposed the transmutation of species, such as those associated with Lamarck, Geoffroy Saint-Hilaire, and eventually Charles Darwin. The difficulties he created for himself in seeking to protect both his scientific originality and his reputation for piety have been beautifully exposed by Evelleen Richards ${ }^{73}$.

We find Owen in Paris during July 1831 . He had been invited by Cuvier and he stayed until early September. His accommodation was at the Hotel du Jardin du Roi, where another British guest was in residence. This was Robert Grant, Professor of Comparative Anatomy at the new London University. The coincidence is fascinating because Owen and Grant subsequently became political rivals, competing for scientific kudos and position ${ }^{74}$. The engaging point is that Grant was an explicit Lamarckian who had already collaborated with Geoffroy Saint-Hilaire. As Adrian Desmond has suggested, it is likely that Grant would have defended Geoffroy in Owen's presence ${ }^{75}$, just as Cuvier attacked him. In Owen's diary there was an entry for 20 August 1831 which recorded that he had spent the evening at Cuvier's where a long conversation about the Orang-Outang had ensued. Cuvier had confessed that he had never dissected a chimpanzee, but he was going to write "contra Geoffroy " ${ }^{76}$.

Owen returned to England familiar with the dispute between Cuvier and Saint-Hilaire. He would also be aware that republican ideals were more likely to be in alliance with Geoffroy's transformist position. But which side would he take? Desmond has identified the pressures which swayed Owen towards the more conservative morphology. The cultural influences which had informed his education had been in line with the perspectives of Coleridge which made the godless materialism of the French philosophers responsible for the Terror. In England, it became clear to Owen that Grant was on the side of political radicals, seeking to destroy the monopoly of the College of Surgeons. And since Owen would be aware that the mood in London created no audience for French

context for scientific and intellectual debate in Britain during the first half of the 19th century, see Robert M. YouNG, Darwin's Metaphor: Nature's Place in Victorian Culture, Cambridge, Cambridge University Press, 1985.

73. Evelleen RICHARDS, "A Question of Property Rights : Richard Owen's Evolutionism Reassessed ", Brit. J. Hist. Sci., 20, 1987, p. 129-171.

74. Cf. A. DESMOND, art. cit. supra n. 39, p. 216-220.

75. Cf. ID., art. cit. supra n. 69, p. 28.

76. Ibid., p. 28-29. 
transformism, his career prospects would be best served by the adoption of anti-evolutionary strategies ${ }^{77}$.

Owen's tactics became clear in a paper which he published on the orang and chimpanzee in $1835^{78}$. In this he attacked Lamarck, Geoffroy and Bory Saint-Vincent. They were wrong, he claimed, in seeing a gradual transition from the skulls of monkeys to those of men. When he began reconstructing dinosaurs from their fossil remains, he also made sure that they were out of step with schemes of transformation ${ }^{79}$. If Lyell was haunted by Lamarck, Owen in turn was haunted by Saint-Hilaire. The idea which both caught his imagination and tormented him was Geoffroy's claim, against Cuvier, that there was a single structural type to which all vertebrates could be referred.

By dividing the animal world into four basic types, Cuvier had preempted any possibility of evolution across the boundaries between them. But Geoffroy's doctrine of a unity of composition clearly lent itself to an evolutionary explanation - in that a unity of plan was what one might expect if all species were derived from a common ancestor. This is not to say that Geoffroy himself had sought to develop a systematic theory of organic evolution. Whilst he argued for the direct action of the environment in inducing organic change, he limited his discussion to a few specific cases - whether, for example, the steneosaurus and teleosaurus, named by himself, were the ancestors of modern gavials ${ }^{80}$. In Appel's interpretation, Geoffroy was «more concerned with proving that the subtle fluids in the environment could modify a common plan of organization, than in insisting that all animals had been derived from each other $"{ }^{81}$. This is, however, a rather loose characterization of evolutionary theory and there is no doubt that Geoffroy's scheme, whatever its limitations, was perceived in England as a threat.

One of the reasons for this was that an emphasis on structural unity could be used to expose the limitations of teleological reasoning - much as Laplace had done in the inorganic sphere. Geoffroy's point was that, in order to understand organic structures and their role in the organism, it was important not to concentrate on function alone, but on the relationship between the structure and the unified plan. It was possible to develop this approach with some sophistication because it helped to

77. Ibid., p. 30-34.

78. Richard OwEN, "On the Osteology of the Chimpanzee and Orang Utan ", Transactions of the Zoological Society, 1, 1835, p. 343-379.

79. A. DESMOND, "Designing the Dinosaur: Richard Owen's Response to Robert Edmond Grant ", Isis, 70, 1979, p. 224-234.

80. Cf. T. A. APPEL, op. cit. supra n. 3, p. 243-244.

81. Ibid., p. 254 ; see also E. S. Russell, op. cit. supra n. 23, p. 66, 69, 73. 
explain why some features of living organisms appeared to have no immediate purpose. What Darwin would call rudimentary and vestigial organs, even the male nipples so much discussed in England, could be rationalized via the concept of a unity of plan.

There are striking resemblances between Owen and Saint-Hilaire because Owen eventually realized that it was too naive to regard living organisms as if every detail had been designed for a specific function. It may even be, as Dov Ospovat suggested, that the rapidly increasing diversity of man-made machines, in which every part did have a function but in which there was no general pattern or plan, assisted this emancipation from William Paley's straightforward equation of animals with machines ${ }^{82}$. In the writings of the British physiologist, William Carpenter, this emancipation reached its zenith with the proposition that Paley's teleological argument was an inadequate basis for natural theology because it could be so easily evacuated by concepts of natural selection which allowed nature to counterfeit design ${ }^{83}$.

An example discussed by Owen, and subsequently by Whewell, concerned the process of ossification in the development of mammalian embryos. It was known that, as the bones formed in the head, the process began in several centres. In the early stages, this allowed the head to be compressed, thereby facilitating birth. In standard works on natural theology, this was presented as evidence of design. It was a divine provision. As Owen pointed out, however, the argument began to look a bit thin when it was discovered that the same mode of formation occurred in birds and animals which were born from an egg. Whewell had to agree with Owen that « in this way, the admission of a new view as to a unity of plan will almost necessarily displace and modify some of the old views respecting final causes ${ }^{84}$.

Owen therefore had a role in acquainting British audiences with the work of Geoffroy. But, at the same time, he modified its meaning by manipulating it into a revised form of natural theology. Owen's solution was to take the unity of plan and turn it into an archetype. It had been an idea in the mind of the Creator. By constructing a natural theology on the concept of a skeletal archetype for all the vertebrates, Owen believed he could sustain the argument for design, despite the challenge from radicals in both London and Paris. The teleological argument survived in a form which stressed the adaptation of the archetype to the particular

82. Cf. D. Ospovat, art. cit. supra n. 47 , p. 36.

83. Ibid., p. 47.

84. W. WHEWELL, History of the Inductive Sciences, $3^{\text {rd }}$ ed., London, 1857, London, Cass Reprint, 1967, vol. 3, p. 559. 
needs of particular species. In constructing the argument, he looked to Germany for inspiration, especially to the transcendentalism of Lorenz $\mathrm{Oken}^{85}$. In a lengthy discussion of the vertebrate skeleton for the British Association, he spoke of the antagonism between two forces, the platonic idea which was responsible for diversity of form, and a " general polarizing force " to the operation of which «the similarity of forms, the repetition of parts, the signs of the unity of organization may be mainly ascribed " ${ }^{86}$. The self-conscious manner in which he drew on German Naturphilosophie was evident in his complaint that the English language lacked the vocabulary to describe that " essentiality " which the part of an animal body retained under every modification of size and form. He much preferred the German "Bedeutung " to signify "that essential character of a part which belongs to it in its relation to a predetermined pattern, answering to the idea of the Archetypal World in the Platonic cosmogony ${ }^{87}$.

The interplay of polar forces allowed Owen to retrieve a teleological argument, for he could still stress the adaptation of the archetype to the needs of the species. Functional considerations were not to be eliminated. There was clearly a reason why in mammals and frogs the long bones should ossify first at their ends, for the brain would then be protected from concussion ${ }^{88}$. As Desmond has so rightly put it, "Owen's God was still a British craftsman working to a blueprint ${ }^{89}$. The contrast with Goethe's vision is striking, for he had made the shaping, moulding power immanent in all life ${ }^{90}$.

Owen's archetype was not merely a device to save natural theology. It played a constitutive role in his science, serving as a standard by which he could measure the degree of specialization as he studied fossil bones. He could trace, for example, the progressive departure of horses from a five-toed ancestor to the modern horse with its one toe ${ }^{91}$. Nevertheless, the theological connotations of Owen's science were a valuable resource when he was forced to defend himself against the charge of infidelity ${ }^{92}$.

85. Roy M. MACLeOD, « Evolutionism and Richard Owen, 1830-1868: An Episode in Darwin's Century ", Isis, 56, 1965, p. 259-280; A. Desmond, Archetypes and Ancestors, London, Blond \& Briggs, 1982, p. 42.

86. R. OWEN, "On the Vertebrate Skeleton ", Report of the 1846 Meeting of the British Association for the Advancement of Science, London, 1847, p. 240-340, especially p. 240253, 339-340.

87. ID., On the Nature of Limbs, London, John Van Voorst, 1849, p. 1-3; Philip F. REHBOCK, The Philosophical Naturalists, Madison, University of Wisconsin Press, 1983, p. 83.

88. Cited by E. S. Russell, op. cit. supra n. 23, p. 110.

89. Cf. A. DeSMOND, op. cit. supra n. 85 , p. 48.

90. Cf. E. S. RUSSELL, op. cit. supra n. 23 , p. 50.

91. Cf. A. DESMOND, op. cit. supra n. 85, p. 44.

92. Cf. J. H. BROOKE, art. cit. supra n. 72; E. RICHARDS, op. cit. supra n. 73, p. 165-167. 
It is not clear that references to design in nature would allay all suspicion. Too great an emphasis on natural, as distinct from revealed, theology could also invite clerical censure ${ }^{93}$. But, in Owen, as in Buckland, Lyell and Whewell, the threat of radical French science was neutralized by absorbing it within the structures of natural theology. And in the process, the case for affirming intelligent design was once again transformed.

\section{CONCLUSION : THE TRANSFORMATION AND DIVERSIFICATION OF NATURAL THEOLOGY}

Among the more eminent French naturalists of the first half of the 19th century, there were few indeed who sought to integrate science and religion in ways which allowed the former to give support to the latter. An exception, who proves the rule, was Henri de Blainville whose representation of the chain of being interlocked with a defence of Catholic christianity ${ }^{94}$. Yet the reaction to Blainville's metaphysics shows how a sharp differentiation, even a separation, of science from religion had become the norm. After reading his Histoire des sciences de l'organisation, his friend, Constant Prévost, responded with these questions :

"To make faith the basis of science - would that not submit the latter to despotism? To deliver faith to the uncertainties of science - would that not expose the former to anarchy? $" 95$.

It is interesting to speculate how the British naturalists we have been considering would have replied to those questions. They would certainly have denied that their natural theology encouraged despotism. One of its traditional functions had been to provide a basis in reason for uniting men of disparate religious beliefs against the potential despotism of extremists ${ }^{96}$. As for delivering faith to the uncertainties of science, there was a degree of confidence among British naturalists that certainties could be distinguished from uncertainties. There was also an awareness of the problem, for one of the points that Brewster scored against

93. Cf. J. Morrell, A. Thackray, op. cit. supra n. 53, p. 229-245. The difficulties experienced by Baden Powell in Oxford, as he sought to develop a consistent and acceptable natural theology, are sensitively discussed by Pietro CORSI, Science and Religion : Baden Powell and the Anglican Debate, 1800-1860, Cambridge, C.U.P., 1988.

94. T. APPEL, « Henri de Blainville and the Animal Series : A Nineteenth-Century Chain of Being ", J. Hist. Biol., 13, 1980, p. 291-319.

95. Cited in ibid., p. 314.

96. Cf. J. H. BroOKE, op. cit. supra n. 6, 1979 et 1987. 
Whewell was that it might prove injurious to faith to base the argument for design on so uncertain a concept as the ether ${ }^{97}$. But for Whewell the strongest argument for design was that certain truth could be, and had been, achieved in science. To look to science for indications (though emphatically not proof) of a Creator was not, in his opinion, a metaphysical error ${ }^{98}$.

The urgency with which powerful scientific figures in Britain tried to divest French science of its materialist implications was not the consequence only of events in France. The importance of a recent study by Desmond consists in his demonstration that among the spokesmen for working class radicalism in England, the science of Lamarck was given a meaning which made it a symbol of democratic aspiration and the abolition of privilege. Lamarck's environmentalism was even invoked to support socialist arguments for female emancipation ${ }^{99}$. Militant writers associated with The Oracle of Reason, an illegal organ of atheist grievance, were giving their own meaning to scientific innovation. William Chilton publicized the nebular hypothesis and the fossil record as « facts which support atheism ", no matter what " respectable men " might prefer ${ }^{100}$.

Not surprisingly, those respectable men who popularized French science in Britain did prefer to invest it with a different set of cultural meanings. As we have seen, the categories of natural theology were retained to neutralize the threat. But in the very process, the form of natural theology was itself changed. It became more sophisticated, but more fragile.

Buckland had protected the concept of design by reconstructing the life-style of extinct species on the assumption that they had been perfectly designed for the conditions in which they had lived. This allowed a scheme of progressive creation which proved very popular until it was overtaken by the Darwinian model. Buckland's system was, however, fragile in at least two respects. Despite its optimistic tone, it had to make extinction part of the divine plan. Inferences to a beneficent God became even less secure and for some observers the noise of the geologists' hammer was repulsive because it proclaimed the indifference of nature. Secondly, as Lyell perceived, schemes of progressive creation could easily be reinterpreted in evolutionary terms. One of the great ironies of 19thcentury British science is that Darwin's secular view of evolution was

97. ID., art. cit. supra n. 50, p. 248-250.

98. ID., art. cit. supra n. 61 .

99. Cf. A. DESMOND, art. cit. supra n. 8, p. 83.

100. Cited in ibid., p. 93-94. 
most closely anticipated in interpretations of the fossil record which had been devised to combat earlier schemes of evolution. Fossils which could be used to embarrass the essentially linear series of Lamarck, were subsequently reinterpreted in accordance with Darwin's image of a branching tree ${ }^{101}$. This gives special poignancy to the common statement that natural theology in Britain dug its own grave.

In response to Lamarck, Lyell had constructed a model of Earth history in which natural theology still had a residual structural role. New species were in some sense pre-adapted to the receptive environment in which they had been introduced. Where such propitious environments existed, the appropriate life-forms would be found. But Lyell's vision was also vulnerable in two respects. It was open to empirical refutation in that many habitats were discovered where the corresponding flora and fauna were conspicuous by their absence. Darwin was struck by this on his Beagle voyage, as he was also by the fact that indigenous species often seemed less well adapted to their region than immigrants ${ }^{102}$. By suggesting that natural causes could be at work in the forging of new species, Lyell also sanctioned the possibility of a thorough scientific naturalism, even if he always stopped short at man.

In response to Laplace, Whewell developed a natural theology which also sanctioned the extension of natural law. Not that he would ever admit that every feature of creation could be explained by natural causes. In his sermons he preserved a role for divine fiat and for the unique status of the human mind. He also made the far-sighted observation that the extension of scientific knowledge created new domains of ignorance ${ }^{103}$. But Whewell's natural theology was also fragile in two respects. He admitted that, even among Christians, the regularities of nature did not inspire a sense of dependence on God as they should. In fact, he rationalized the cholera epidemic which hit Cambridge in 1849 by suggesting, not that it was a punishment, but that it was a reminder that God did not wish to be forgotten ${ }^{104}$. Similarly, Whewell's traditional argument that laws presupposed a Legislator could be self-defeating if the laws were transferred from the context of inorganic to organic development. The development hypothesis which Chambers promoted in Vestiges was anathema to him. The ultimate irony, whereby natural theology

101. Peter Bowler, Fossils and Progress: Paleontology and the Idea of Progressive Evolution in the Nineteenth Century, New York, Science History Publications, 1976; cf. A. DESMOND, op. cit. supra n. 85 , p. 56:83.

102. Cf. M. J. S. HoDGE, art. cit. supra n. 46.

103. W. WHEWELl, Sermon, 20 Feb. 1827, Trinity College Cambridge, R. 6, 17

104. ID., A Sermon Preached before the University of Cambridge on the Day of the General Thanksgiving, 15 Nov. 1849, Cambridge, 1849, p. 10-12. 
was tailored to fit an exhaustive naturalism, was transparent in the frontispiece to Darwin's Origin of Species, where Whewell was quoted to gain tacit approval for naturalizing human origins. The passage which Darwin lifted reads as follows : "With regard to the material world, we can at least go so far as this - we can perceive that events are brought about not by insulated interpositions of Divine power, exerted in each particular case, but by the establishment of general laws. " A natural theology of the material world could easily become the Trojan horse of scientific naturalism if the boundaries between material and spiritual were not clearly drawn ${ }^{105}$.

Owen's shift of emphasis from Paley's teleological argument to arguments based on the unity of type was a sophisticated move, but it, too, had its attendant weakness. In order to see evidence of divine intelligence one had to distinguish that aspect of an organic structure which reflected unity of type from that which showed the modification of the type for specific purposes. It was necessary to have expert knowledge to decode the architecture. This meant that the traditional argument from design lost its clarity and, with it, its appeal to the uninitiated. Whewell confessed as much in 1860 :

«with regard to the Design which we see in the organs of living things, though we can confidently say we see it, how obscurely is it shown, and how much is our view of it disturbed by other laws and analogies » 106 .

In many cases, the efficiency of adaptation seemed to be sacrificed in order to maintain a coherence of structure ${ }^{107}$. Moreover, an emphasis on the convergence of structure was vulnerable to the Darwinian critique which stressed divergence from common ancestors. By the $1860 \mathrm{~s}$, Owen himself was emphasizing specialism and divergence rather than the common structure ${ }^{108}$.

In the period which preceded Darwin's Origin of Species natural theology in England underwent considerable diversification. Under pressure from the historical sciences, it was able to adapt rather than suffer extinction. But its new fragility meant that in the post-Darwinian controversies, it was extremely difficult to sustain. There is, as always, an irony in the story. In their attempts to neutralize the subversive elements in

105. John R. DuRaNT, «The Meaning of Evolution: Post-Darwinian Debates on the Significance for Man of the Theory of Evolution ", University of Cambridge, Ph. D. Dissertation, 1977, p. 55-96; cf. J. H. BROOKE, art. cit. supra n. 56, p. 208; P. J. BOWLER, "Darwinism and the Argument from Design: Suggestions for a Reevaluation ", J. Hist. Biol., 10, 1977, p. 29-43, 43.

106. W. WHEWEL, On the Philosophy of Discovery, London, 1860, p. 378.

107. Cf. P. J. BOWLER, art. cit. supra n. 105, p. 32-33.

108. Ibid., p. 37. 
French science, the British naturalists only succeeded in giving them further publicity. Readers with other assumptions could easily remove the wrapping of natural theology and sometimes preferred what they saw underneath. The same William Chilton who saw in respectability an obstacle to the true meaning of science, had picked up his knowledge of Lamarck at least in part from Lyell's refutation ${ }^{109}$. And it was not only the disrespectable who reacted against the refutation. Herbert Spencer confessed that on reading Lyell's exposition he had been more persuaded by Lamarck than by his critic ${ }^{110}$. A similar problem arose in connection with Owen's machinations. The Oxford mathematician and philosopher Baden Powell studied Owen's treatment of the archetype. But he then put Owen on the spot by asking whether it did not make more sense to see the unity of type as evidence for transformation. Saint-Hilaire was cited as a precedent ${ }^{111}$ !

With one further example of this ironic pattern, I shall conclude. It concerns a quite different pair : the response of Darwin to the positivist philosophy of Comte. During 1838, Darwin learnt of Comte through the summary of the Cours which Brewster published in the Edinburgh Review ${ }^{112}$. Brewster showed some sympathy for Comte's philosophy but, true to form, objected to Comte's dismissal of final causes. Since Darwin already had his own reasons for being wary of final causes, he found himself rejecting Brewster's rejection of Comte's rejection! Claims for the seminal influence of Comte on Darwin have doubtless been exaggerated ${ }^{113}$. It is also clear that Comtean positivism in France became a resource for attacking the scientific credentials of Darwinism ${ }^{114}$. But there is no doubt that Darwin himself took some comfort from one who, in August 1838, appeared to be a kindred spirit. In his socalled metaphysical notebook, Darwin wrote: «M. Le Comte argues against all contrivance $[. .$.$] it is what my views tend to { }^{115}$. Earlier, on

109. Cf. A. Desmond, art. cit. supra n. 8, p. 99.

110. Herbert SPENCER, An Autobiography, London, 1904, vol. 1, p. 176 ; cf. M. BaRTHOLOMEW, art. cit. supra n. 40, 1973, p. 278.

111. Cf. A. Desmond, op. cit. supra n. 85, p. 46.

112. Cf. E. MANIER, op. cit. supra n. 57.

113. The claims made in Silvan S. SCHWEBER, "The Origin of the Origin Revisited", J. Hist. Biol., 10, 1977, p. 229-316, have recently been challenged in M.J.S. HoDGE, D. KoHN, "The Immediate Origins of Natural Selection", in D. KoHN, op. cit. supra n. 38 , p. 192.

114. Yvette CONRY, L'Introduction du darwinisme en France au XIX siècle, Paris, Vrin, 1974 ; P. Corsi, Paul J. WeIndling, "Darwinism in Germany, France and Italy ", in D. KoHN, op. cit. supra n. 38, p. 683-729, 702. See also the essays by H. Paul and R. E. Stebbins in Thomas F. GLICK, ed., The Comparative Reception of Darwinism, Austin, University of Texas Press, 1974.

115. Cf. E. MANIER, op. cit. supra n. 57, p. 41 et 167. 
his great voyage of discovery, he had been struck by the belief of savages that thunder and lightning were the direct will of God. Now he saw how such beliefs would exemplify what Comte had called the theological age of science ${ }^{116}$. There can be no doubt as to which of Comte's three ages Darwin perceived himself to adhere. In the fertile mind of England's greatest naturalist, French and English perspectives had for once coincided.

John Hedley BROOKE, University of Lancaster

(Great-Britain).

116. Howard E. Gruber, Paul H. Barrett, Darwin on Man : A Psychological Study of Scientific Creativity. Together with Darwin's Early and Unpublished Notebooks, New York, E.P. Dutton, 1974. The $M$ notebook entries 69 and 135-136. On the seminal role which Darwin's study of the Fuegians played in the development of his thinking see J. R. DURANT, "The Ascent of Nature in Darwin's Descent of Man ", in D. KoHN, op. cit. supra n. 38, p. 283-306. 